children were classified as mild or moderate. ${ }^{10}$ Recent studies suggest that both prevalence and severity of childhood asthma are increasing. ${ }^{1220}$ The factors responsible for these increases may worsen the prognosis and adversely affect social outcomes.

We thank Joyce Leys for technical help and John Lemon for computing advice. This work was supported by grants from the National Asthma Campaign and Allen and Hanburys Limited.

1 Ninan TK, Russell G. Respiratory symptoms and atopy in Aberdeen schoolchildren: evidence from two surveys 25 years apart. BMF 1992;304: 873-5.

2 Robertson CF, Heycock E, Bishop J, Nolan T, Olinsky A, Phelan PD. Prevalence of asthma in Melbourne schoolchildren: changes over 26 years. BMF 1991;302:1116-8.

3 Strachan DP, Anderson HR, Bland JM, Peckham C. Asthma as a link between chest illness in childhood and chronic cough and phlegm in young adults. chest illness in childhood

4 Britten N, Davies JMC, Colley JRT. Early respiratory experience and subsequent cough and peak expiratory flow rate in 36 year old men and women. BMF 1987:294:1317-20

Martin AJ, McLennan LA, Landau LI, Phelan PD. The natural history of childhood asthma to adult life. $B M J$ 1980;280:1397-400.

6 Martin AJ, Landau LI, Phelan PD. Asthma from childhood at age 21: the patient and his disease. BMF 1982;284:380-2.

7 Kelly WJW, Hudson I, Raven J, Phelan PD, Pain MCF, Olinsky A. Childhood asthma and adult lung function. Am Rev Respir Dis 1988;138:26-30.
8 Kelly WJW, Hudson I, Phelan PD, Pain MCF, Olinsky A. Childhood asthma in adult life: a further study at 28 years of age. $B M \mathcal{F} 1987 ; 294: 1059-62$.

Sibbald B, Anderson HR, McGuigan S. Asthma and employment in young adults. Thorax 1992;47:19-24.

10 Dawson B, Horobin G, Illsley R, Mitchell R. A survey of childhood asthma in Aberdeen. Lancel 1969;i:827-30.

11 Mitchell RG, Dawson D. Educational and social characteristics of children with asthma. Arch Dis Childhood 1973;48:467-71.

12 Higgins BG, Britton JR, Chinn S, Jones TD, Jenkinson D, Burney PGJ, et al. The distribution of peak expiratory flow variability in a population sample. Am Rev Respir Dis 1989;140:1368-72.

13 Goldthorpe JH, Llewellyn C. Class mobility in Britain: three theses examined. In: Goldthorpe JH, ed. Social mobility and class structures in modern Britain. Oxford: Clarendon, 1987:39-42.

14 Speight ANP, Lee DA, Hey EN. Underdiagnosis and undertreatment of asthma in childhood. BMf 1983;286:1253-6.

15 Anderson HR, Bailey PA, Cooper JS, Palmer CJ, West S. Morbidity and school absence caused by asthma and wheezing illness. Arch Dis Childhood 1983;58:777-84.

16 Strachan DP, Elton RA. Relationship between respiratory morbidity in children and the home environment. Family Practice 1986;3:137-42.

17 McCarthy P, Byrne D, Harrison S, Keithley J. Respiratory conditions: effect of housing and other factors. F Epidemiol Community Health 1985;39:15-9.

18 Nocon A, Booth T. The social impact of asthma. Sheffield: Joint Unit for Social Services Research, University of Sheffield, 1989.

19 Grampian Regional Council Department of Physical Planning. Labour market. Grampian Quarterly Economic Review 1989-90; Winter:17.

20 Anderson HR. Increase in hospital admissions for childhood asthma: trends in referral, severity, and readmission from 1970 to 1985 in a health region of the United Kingdom. Thorax 1989;44:614-9.

\section{GREAT Group}

Members of the group are listed at the end of this report

Correspondence to: Dr J M Rawles, Medicines Assessment Research Unit, University of Aberdeen, Foresterhill, Aberdeen AB9 2ZD.

BMF 1992:305:548-53

\title{
Feasibility, safety, and efficacy of domiciliary thrombolysis by general practitioners: Grampian region early anistreplase trial
}

\author{
GREAT Group
}

Abstract

Objective-To assess the feasibility, safety, and efficacy of domiciliary thrombolysis by general practitioners.

Design-Randomised double blind parallel group trial of anistreplase 30 units intravenously and placebo given either at home or in hospital.

Setting-29 rural practices in Grampian admitting patients to teaching hospitals in Aberdeen (average distance 36 (range 16-62) miles).

Patients -311 patients with suspected acute myocardial infarction and no contraindications to thrombolytic therapy seen at home within four hours of onset of symptoms.

Main outcome measures-Time saving, adverse events, $Q$ wave infarction, left ventricular function.

Results-Anistreplase was administered at home 101 minutes after onset of symptoms, while anistreplase was given in hospital 240 minutes after onset of symptoms (median times). Adverse events after thrombolysis were infrequent and, apart from cardiac arrest, not a serious problem when they occurred in the community: seven of 13 patients were resuscitated after cardiac arrest out of hospital. By three months after trial entry the relative reduction of deaths from all causes in patients given thrombolytic therapy at home was $49 \%(13 / 163$ $(8.0 \%) \vee 23 / 148$ (15.5\%); difference $-7.6 \%(95 \%$ confidence interval $-14 \cdot 7 \%$ to $-0 \cdot 4 \%$ ), $p=0 \cdot 04$ ). Full thickness $Q$ wave infarction was less common in patients with confirmed infarction receiving treatment at home $(65 / 122(53.3 \%) v 76 / 112(67.9 \%)$; difference $-14 \cdot 6 \%$ (95\% confidence interval $-27 \cdot 0 \%$ to $-2 \cdot 2 \%), \mathrm{p}=0 \cdot 02$ ).

Conclusions-General practitioners provided rapid pre-hospital coronary care of a high standard. Compared with later administration in hospital, giving anistreplase at home resulted in reduction in mortality, fewer cardiac arrests, fewer $Q$ wave infarcts, and better left ventricular function. Benefits were most marked where thrombolytic therapy was administered within two hours of the onset of symptoms.

\section{Introduction}

The strong theoretical case for giving thrombolytic therapy as early as possible after myocardial infarction is supported by experimental work, ${ }^{12}$ but evidence from clinical trials is equivocal. Additional benefit with earlier treatment has been reported in some studies ${ }^{34}$ but not in others. ${ }^{56}$ In the recently reported European myocardial infarction project ${ }^{7}$ administration of anistreplase in the community resulted in a $17 \%$ reduction of cardiac mortality compared with administration in hospital (presented at a meeting of the American College of Cardiology, Dallas, April 1992).

In mainland Britain, although the case for early thrombolytic therapy is generally accepted, there is no system for providing pre-hospital coronary care, and doubts have been expressed about the competence of general practitioners to give thrombolytic therapy and whether there would be any worthwhile saving of time if they were to do so. ${ }^{8}$ It has been suggested that the best policy would be for patients with suspected myocardial infarction to call an ambulance directly and bypass the general practitioner.'

The objectives of the Grampian region early anistreplase trial were to study the feasibility, safety, and efficacy of domiciliary thrombolysis by general practitioners. Anistreplase was used in preference to streptokinase because it is given intravenously by bolus injection rather than by slow intravenous infusion; the convenience of use of anistreplase makes it the thrombolytic agent of choice for domiciliary use.

Thrombolysis is but one element of pre-hospital coronary care, other vital ingredients being speed of response, clinical assessment and diagnosis, relief of 
pain and anxiety, correction of autonomic disturbances and arrhythmias, and resuscitation. In this study al these aspects of care were monitored, and they also form the subject of this report.

\section{Practitioners, patients, and methods PRACTICES}

Twenty nine practices participated in the trial, which ran for 37 months, from December 1988 to 31 December 1991. Five of the practices had previously taken part in a study of the use of defibrillators in the community. ${ }^{1011}$ The practices were located in country towns and villages 16-62 (mean 36 ) road miles from Aberdeen. They ranged in size from single handed (list 515 ) to eight partners (list 15500 ). All group practices were organised so that one doctor was on call for emergencies each day and could be contacted by cellular telephone, message pager, or two way radio Every practice was equipped with an electrocardiograph and a defibrillator.

\section{HOSPITALS}

All patients were referred to teaching hospitals in Aberdeen and admitted to the coronary care unit if there was a bed available; otherwise, patients were admitted to any of nine general medical wards by rota.

\section{INCLUSION AND EXCLUSION CRITERIA}

Entry to the trial was by strong clinical suspicion of acute myocardial infarction by the general practitioner. Symptoms characteristic of myocardial infarction had to have been present for at least 20 minutes but not more than four hours. It had to be possible for the patient to get to Aberdeen within six hours of the onset of symptoms. The general practitioner was required to record an electrocardiogram but did not have to interpret it for trial entry. Verbal consent to enter the study was obtained from patients or their relatives.

Exclusion criteria were thrombolytic therapy within the past six months; surgery or major trauma in the past 10 days; active gastrointestinal bleeding or a history of any other internal bleeding within the past six months; cerebrovascular accident or neurosurgical procedure within two months or a known intracranial neoplasm or aneurysm; history of thrombocytopenia or haemorrhagic diathesis or anticoagulant treatment; risk of pregnancy or heavy vaginal bleeding; diabetic proliferative retinopathy; blood pressure more than 200/120 mm Hg; recent resuscitation with chest compression; previous entry into the trial; and participation in another clinical trial.

The study was approved by the joint ethical committee of Grampian Health Board and the University of Aberdeen.

\section{CONDUCT OF STUDY}

Home

Practitioners were provided with trial packs consisting of paired ampoules of anistreplase, 30 units, and matching placebo. The ampoules were randomly labelled "home injection" and "hospital injection" by the supplying pharmaceutical company, which held the code. Trial packs were issued to practices in numerical order and kept in a refrigerator. Many doctors had a pack at home as well as a supply in their surgery.

Called to a patient with suspected myocardial infarction, the doctor carried out his usual assessment and treatment, and an electrocardiogram was recorded. If the patient was eligible for the trial "home injection" was administered by slow intravenous injection over five minutes after authorisation from the trial coordinator, who, meanwhile, arranged admission to hospital on the general practitioner's behalf. The "hospital injection" was then sent with the patient to Aberdeen. In some cases, at the doctor's discretion, he or she accompanied the patient, but by the end of the trial ambulances were equipped with defibrillators under the Heartstart Scotland scheme, ${ }^{12}$ making a medical escort less necessary.

The general practitioner noted the following times on a structured referral letter: onset of patient's symptoms, call for doctor, arrival of doctor at the patient's home, and time of home injection. Other clinical information was also recorded on the same document.

\section{Hospital}

In Aberdeen the patient was taken directly to the coronary care unit or general medical ward, there to be assessed by the admitting physician. An electrocardiogram was recorded. A return phone call to the trial coordinator was then required to report any complications that had arisen during the journey to hospital, to check that there were still no contraindications to thrombolytic therapy, and to ascertain whether the admitting doctor had an alternative diagnosis to that of the referring general practitioner. If the admitting physician did not agree with the referring doctor's assessment but could establish no alternative diagnosis the protocol required that the hospital injection should be given. Only if there were contraindications or a proved alternative diagnosis was the hospital injection to be withheld. The time of the hospital injection was noted.

Blood was taken on admission and on each of the next three days for assay of the myocardial isoenzyme of creatine kinase (MB). The electrocardiogram was repeated on each of the next three days and at discharge.

Daily measurements of stroke distance were made in the arch of the aorta through the suprasternal window by means of a non-imaging Doppler ultrasound instrument. ${ }^{13}$ An average of the number of beats in 10 seconds was obtained. Mean stroke distance was expressed as a percentage of the age predicted normal value. ${ }^{14}$ The measurement at discharge or 10 days, whichever was the earlier, was used for analysis.

\section{DIAGNOSTIC DEFINITIONS}

At the time of discharge each patient was assigned to one of the seven following diagnostic categories by using data collected in hospital.

Definite myocardial infarction was recorded when there was a convincing history plus new pathological Q waves in the electrocardiogram and a peak creatine kinase $\mathrm{MB}$ value exceeding the upper limit of normal.

Probable myocardial infarction was recorded when there was a convincing history plus either new pathological $Q$ waves or a raised creatine kinase $M B$ value.

Possible myocardial infarction was recorded when there was a convincing history plus abnormalities in the electrocardiogram not characteristic of myocardial infarction and an increase in cardiac enzyme values other then creatine kinase MB.

Ischaemic heart disease was recorded when there was a history of previous myocardial infarction or angina without new electrocardiographic or enzyme changes.

Chest pain of unknown cause was recorded when there was no history of previous myocardial infarction or angina and no electrocardiographic or enzyme evidence to suggest an event at this admission and no other cause for chest pain was found.

Alternative diagnosis was a proved alternative diagnosis to any of the above.

Pre-hospital death was death after home injection but before hospital injection, occurring either in the 
community or immediately on arrival in hospital. As an indication of infarct size infarcts were classified as showing new $Q$ waves or not. A pathological $Q$ wave was defined as an initial negative deflection in any lead other than aVR that was at least 0.04 seconds in duration and with an amplitude at least $25 \%$ of the ensuing $R$ wave.

\section{STATISTICAL CONSIDERATIONS}

The primary purpose of the trial was to study the feasibility and safety of thrombolytic therapy, efficacy being a secondary objective. The target number of patients to be recruited over two years was 500 , which would have given $80 \%$ power to confirm or exclude an absolute difference of $10 \%$ in the rate of confirmation of myocardial infarction, $15 \%$ in the rate of $Q$ wave infarction, $5 \%$ in stroke distance, and $8 \%$ in mortality.

At the end of 1990 the decision was taken to terminate the trial at the end of 1991 regardless of the number of patients recruited by that time. It was considered that sufficient information on feasibility and safety would be available by then.

All analyses were by "intention to treat." Patients receiving anistreplase at home and intended to receive placebo in hospital are referred to as the "home" group, and those receiving placebo at home and intended to receive anistreplase in hospital are referred to as the "hospital" group.

The subset of patients who received home injection within two hours of the onset of symptoms, midway through the general practitioners' time window, is of particular interest, as it was anticipated that there would be minimal overlap in the average times of their home and hospital injections.

Two tailed statistical tests were used throughout, $t$ tests for comparison of means and the $\chi^{2}$ test for comparison of proportions. Confidence intervals were calculated by the confidence interval analysis computer program. Statistical significance was taken as $\mathbf{p}<0.05$.

\section{Results}

Eighty nine different general practitioners from 27 practices contributed an average of 3.5 patients each to the trial (range 1-15), giving a total of 311 . Two single handed practices did not contribute any patients. The average rate of recruitment was one patient about every

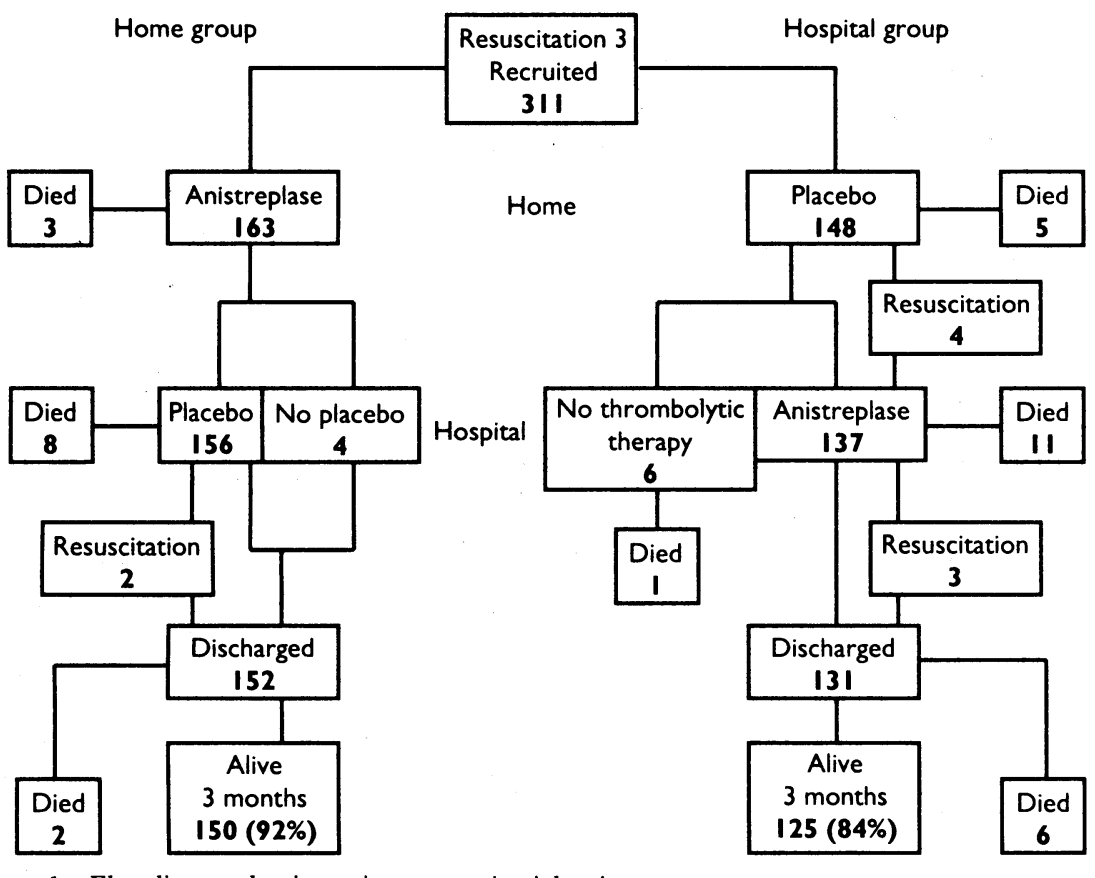

FIG 1-Flow diagram showing major outcomes in trial patients
11 months for each of the doctors who had agreed to participate.

During the trial 187 patients registered with the participating general practitioners received thrombolytic therapy in hospital outwith the trial. The proportion of eligible patients who were recruited was about $60 \%$. A flow diagram showing the main outcomes for all trial patients is given in figure 1 .

\section{GENERAL MANAGEMENT AND RESUSCITATION}

An opiate analgesic was given by the general practitioner in 253 of the 311 cases (81\%), and eight of the patients who were not given opiate received nitrate. Aspirin was given in 261 cases (84\%). Twelve patients were given antiarrhythmic treatment.

There were 17 cardiac arrests in 15 patients that occurred before admission to hospital, including two patients who died while unaccompanied in the ambulance. Resuscitation from pre-hospital cardiac arrest was attempted in 13 patients, seven of whom were discharged.

\section{BASELINE COMPARISON OF GROUPS}

One hundred and sixty three patients were allocated to receive anistreplase at home and 148 to receive it in hospital (table). The two groups were well matched for age, sex, clinical condition, electrocardiographic abnormality, and history of angina, but there were significantly more patients with previous infarction in the home group. Compared with the hospital group a significantly higher proportion of patients in the home group were taking diuretics.

\section{TIME SAVING}

Median time intervals were very similar for the home and hospital groups, and for both groups combined they were: from onset of symptoms to call for general practitioner 45 minutes (range $0-340$ ), from call to arrival of general practitioner $10(0-80)$ minutes, from arrival of general practitioner to home injection ("door to needle") 43 (5-160) minutes, and from home injection to hospital injection ("needle to needle") 130 (40-370) minutes (fig 2). The median times of home and hospital injections after the onset of symptoms were 105 (25-390) and $240(80-540)$ minutes. The median times of injection of active anistreplase at home and in hospital were 101 (25-360) and 240 (80-540) minutes, respectively.

In 37 of the 311 cases (12\%) home injection was given within one hour of the onset of symptoms and in 189 cases $(61 \%)$ within two hours of the onset of symptoms. Two patients $(0 \cdot 6 \%)$ had hospital injection within two hours and none within one hour.

No record of the time of arrival of the ambulance at hospital was kept. However, the average speed of the ambulance was estimated at $46 \mathrm{mph}$, giving an approximate journey time of 47 minutes. Subtracting the journey time from the mean needle to needle time of 134 minutes gives a delay of about 87 minutes; most of this represents door to needle time in hospital. Mean needle to needle times were 122 minutes in the 186 $(60 \%)$ patients admitted to the coronary care unit compared with 152 minutes in those admitted to general medical wards, a difference of 30 minutes.

ADVERSE EVENTS OCCURRING BEFORE ADMISSION TO HOSPITAL

Table II lists all reported adverse events occurring in the community. For comparison the frequency of reporting the same events within three hours of the hospital injection is shown.

Arrhythmias-There was no obvious association between the administration of anistreplase and cardiac arrest. Indeed, death or cardiac arrest was less 
TABLE I-Baseline comparison of patients. Except where stated otherwise figures in parentheses are percentages

\begin{tabular}{lccc}
\hline & Home & Hospital & Total \\
\hline No in group & $163(100)$ & $148(100)$ & $311(100)$ \\
Mean age (years) (range) & $64(41-85)$ & $63(32-93)$ & $63(32-93)$ \\
Male sex & $110(67)$ & $106(72)$ & $216(69)$ \\
Previous myocardial infarction & $45(28)$ & $22(15)$ & $68(22)$ \\
Previous angina & $80(49)$ & $69(47)$ & $149(48)$ \\
Aspirin at home & $136(83)$ & $125(85)$ & $261(84)$ \\
Resuscitation before trial entry & $2(1)$ & $1(1)$ & $3(1)$ \\
Pulse rate (beats/min)(range) & $78(40-180)$ & $77(35-180)$ & $78(35-180)$ \\
Systolic blood pressure (mm Hg)(range) & $134(80-200)$ & $135(60-210)$ & $135(60-210)$ \\
Diastolic blood pressure (mm Hg)(range) & $81(40-112)$ & $82(0-130)$ & $82(0-130)$ \\
Electrocardiogram: & & & \\
$\quad$ ST elevation & $78(48)$ & $81(55)$ & $159(51)$ \\
Non-specific & $59(36)$ & $45(30)$ & $104(33)$ \\
Normal & $12(7)$ & $14(10)$ & $26(8)$ \\
Not available & $14(9)$ & $8(5)$ & $22(7)$ \\
Long term treatment: & & & $65(21)$ \\
$\quad$ Diuretics & $41(25)$ & $24(16)$ & $73(23)$ \\
Nitrates & $41(25)$ & $32(22)$ & $52(17)$ \\
$\beta$ blockers & $33(20)$ & $19(13)$ & $57(18)$ \\
Calcium blockers & $31(19)$ & $26(18)$ & $22(7)$ \\
Aspirin & $13(8)$ & $9(6)$ & $8(3)$ \\
Digoxin & $6(4)$ & $2(1)$ & $4(1)$ \\
Angiotensin converting enzyme inhibitors & $2(1)$ & $2(1)$ & \\
& & &
\end{tabular}

common after anistreplase than after placebo. Sinus bradycardia occurred more often after anistreplase than after placebo and was treated with atropine on three of nine occasions in the community and five of 11 in hospital.

Hypotension-A fall in blood pressure was documented in $60 \%$ of cases after anistreplase, the mean blood pressure falls at home and in hospital being 13/7 and $14 / 6 \mathrm{~mm} \mathrm{Hg}$. However, hypotension as an adverse event was reported in only $7 \%$ of cases. No specific action was taken when hypotension occurred in the home, but in hospital the fall was interpreted as an allergic reaction and treated with hydrocortisone and chlorpheniramine on five occasions.

Other adverse events in community-Facial flushing was reported on six occasions, all in association with active thrombolytic therapy. Four patients complained of severe transient back pain during or shortly after anistreplase injection. This perplexing side effect of thrombolytic therapy has been described previously. ${ }^{15-17}$ Shooting pains in the back were reported in one patient several hours after receiving anistreplase in hospital.

OVERALL INCIDENCE OF ADVERSE EVENTS

The numbers of patients with adverse events occurring before and during hospital admission are given in

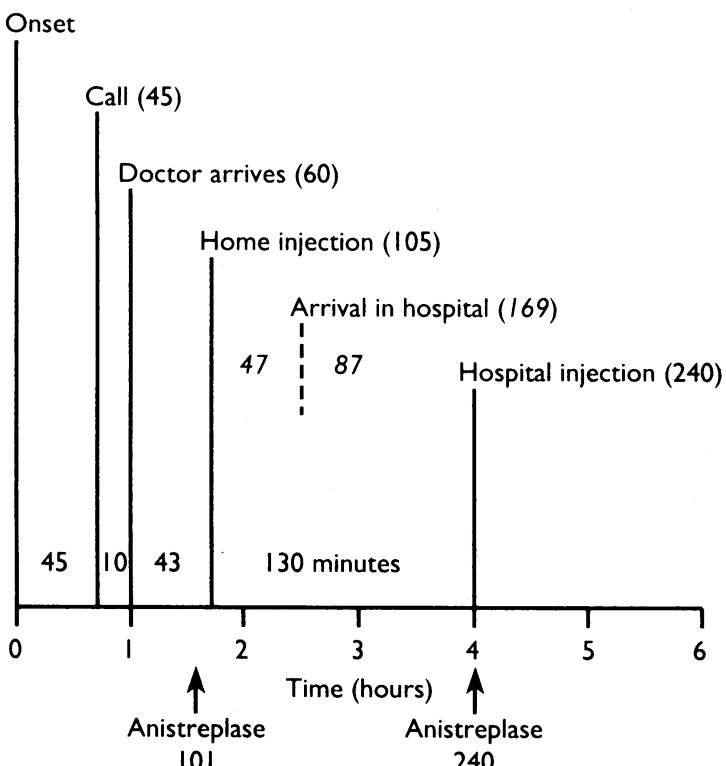

FIG 2-Median time delays (minutes) to thrombolytic therapy in home and hospital groups combined. Estimated means given in italics. (Median time intervals do not sum arithmetically) table III. There were 28 deaths and nine resuscitations from cardiac arrest in the combined groups. Death or resuscitation from cardiac arrest occurred less often in patients given anistreplase at home compared with in hospital $(13 / 163(8 \cdot 0 \%) v 24 / 148(16 \cdot 2 \%)$, difference $-8 \cdot 2 \%(95 \%$ confidence interval $-15 \cdot 5 \%$ to $-1 \cdot 0 \%)$, $\mathrm{p}=0.02)$.

Of the 12 patients with haematemeses, only one required a transfusion; none had significant blood loss before arrival in hospital. Bruising and bleeding from injection sites were no more common where anistreplase was administered in the community rather than in hospital. One patient bled for several days from the site of insertion of a pacemaker wire in the femoral vein.

Transient increases in liver enzyme values have been reported with streptokinase and attributed to the plasmin load on the liver..$^{18}$ Such abnormalities have not previously been reported with anistreplase, but a rise in $\gamma$-glutamyltransferase activity was found in 84 $(27 \%)$ of our cases. Mostly, liver enzyme values were normal by three months.

TABLE II-Numbers of patients with reported adverse events after anistreplase or placebo occurring at home and during journey to hospital or during three hours after injection in hospital

\begin{tabular}{lllll}
\hline & \multicolumn{2}{c}{ Home and journey } & & \multicolumn{2}{c}{ Hospital $<3 \mathrm{~h}$} \\
\cline { 2 - 3 } \cline { 4 - 5 } Adverse event & $\begin{array}{c}\text { Anistreplase } \\
(\mathrm{n}=163)\end{array}$ & $\begin{array}{c}\text { Placebo } \\
(\mathrm{n}=148)\end{array}$ & $\begin{array}{c}\text { Placebo } \\
(\mathrm{n}=156)\end{array}$ & $\begin{array}{c}\text { Anistreplase } \\
(\mathrm{n}=137)\end{array}$ \\
\hline
\end{tabular}

Death

Cardiac arrest

Cerebrovascular event

Shock and left

ventricular failure

Hypotension

Other arrhythmias

Syncope

Flushing

Headache

Nausea

Vomiting

Haematemesis

Minor bleeds, etc

Back pain

Chest pain

Respiratory depression

$\begin{array}{rlll}3 & 5 & 2 & 2 \\ 0 & 4 & 0 & 0 \\ 0 & 0 & 0 & 1 \\ 2 & 2 & 0 & 0 \\ 7 & 0 & 1 & 10 \\ 7 & 2 & 5 & 4 \\ 1 & 2 & 4 & 2 \\ 1 & 1 & 0 & 1 \\ 3 & 3 & 0 & 0 \\ 6 & 0 & 0 & 1 \\ 2 & 1 & 0 & 0 \\ 4 & 1 & 1 & 0 \\ 10 & 9 & 2 & 6 \\ 1 & 2 & 1 & 3 \\ 3 & 1 & 1 & 0 \\ 4 & 0 & 0 & 0 \\ 1 & 0 & 0 & 1 \\ 1 & 0 & 0 & 0\end{array}$

There were significantly fewer deaths from all causes within three months with administration of anistreplase at home rather than in hospital, a relative reduction of $49 \%(13 / 163(8 \cdot 0 \%) v 23 / 148(15 \cdot 5 \%)$, difference $-7 \cdot 6 \%(-14 \cdot 7 \%$ to $-0 \cdot 4 \%) ; p=0 \cdot 04)$.

There were 11 cardiac deaths in the home group and 20 in the hospital group. Administration of anistreplase at home resulted in a $50 \%$ relative reduction in cardiac mortality $(11 / 163$ cases $(6 \cdot 7 \%) v 20 / 148$ $(13.5 \%)$, difference $-6.8 \%(-13.5 \%$ to $-0.04 \%)$; $\mathrm{p}=0.05)$.

\section{DISCHARGE DIAGNOSES}

All eight patients who died before admission and before blood could be taken for assay of cardiac enzyme values were considered to have died of acute myocardial infarction (table IV). With the addition of these patients the proportion of trial patients with the final diagnosis of acute myocardial infarction at any level of certainty (definite, probable, possible) was $78 \%$. There were slightly fewer $(-2 \cdot 4 \%)$ patients with confirmed myocardial infarction in the home treated than in the hospital treated group, but this did not reach statistical significance $(p=0 \cdot 87)$. Thus there was no evidence of averting myocardial infarction by early treatment.

In seven of the 311 cases $(2 \cdot 2 \%)$ an alternative diagnosis was made by the time of discharge from hospital, but in only three of these cases was the correct diagnosis made on admisison. One patient with an alternative diagnosis died. At necropsy she was found 
TABLE III -Numbers (percentages) of patients with adverse events up to time of discharge from hospital

\begin{tabular}{lccc}
\hline Adverse event & $\begin{array}{c}\text { Home } \\
(\mathbf{n}=163)\end{array}$ & $\begin{array}{c}\text { Hospital } \\
(\mathbf{n}=148)\end{array}$ & $\begin{array}{c}\text { Total } \\
(\mathbf{n}=311)\end{array}$ \\
\hline Major: & & & \\
$\quad$ Death & $11(6 \cdot 7)$ & $17(11 \cdot 5)$ & $28(9 \cdot 0)$ \\
Cardiac arrest & $2(1 \cdot 2)$ & $7(4 \cdot 7)$ & $9(2 \cdot 9)$ \\
$\quad$ Cerebrovascular event & $1(0 \cdot 6)$ & $1(0 \cdot 6)$ & $2(0 \cdot 7)$ \\
Minor: & & & \\
$\quad$ Hypotension & $10(6 \cdot 1)$ & $13(8 \cdot 8)$ & $23(7 \cdot 4)$ \\
Bradycardia & $15(9 \cdot 2)$ & $8(5 \cdot 4)$ & $23(7 \cdot 4)$ \\
Other arrhythmias & $21(12 \cdot 9)$ & $19(12 \cdot 8)$ & $40(12 \cdot 9)$ \\
Haematemesis & $3(1 \cdot 8)$ & $9(6 \cdot 1)$ & $12(3 \cdot 9)$ \\
Minor bleeds, etc & $4(2 \cdot 5)$ & $5(3 \cdot 4)$ & $9(2 \cdot 9)$ \\
Rash & $0(0 \cdot 0)$ & $2(1 \cdot 4)$ & $2(0 \cdot 6)$ \\
Flushing & $6(3 \cdot 7)$ & $1(0 \cdot 7)$ & $7(2 \cdot 2)$ \\
Back pain & $4(2 \cdot 5)$ & $1(0 \cdot 7)$ & $5(1 \cdot 6)$ \\
Raised $\gamma$-glutamyltransferase & & & \\
$\quad$ activity & $47(28 \cdot 8)$ & $37(25 \cdot 0)$ & $84(27 \cdot 0)$ \\
\hline
\end{tabular}

TABLE IV - Numbers (percentages) of patients with final diagnoses

\begin{tabular}{lccc}
\hline & Home & Hospital & Total \\
\hline Definite myocardial infarction & $50(30 \cdot 7)$ & $63(42 \cdot 6)$ & $113(36 \cdot 3)$ \\
Probable myocardial infarction & $44(27 \cdot 0)$ & $34(22 \cdot 9)$ & $78(25 \cdot 1)$ \\
Possible myocardial infarction & $28(17 \cdot 2)$ & $15(10 \cdot 1)$ & $43(13 \cdot 8)$ \\
Ischaemic heart disease & $23(14 \cdot 1)$ & $11(7 \cdot 4)$ & $34(10 \cdot 9)$ \\
Chest pain, cause unknown & $12(7 \cdot 4)$ & $16(10 \cdot 8)$ & $28(9 \cdot 0)$ \\
Alternative diagnosis & $3(1 \cdot 8)$ & $4(2 \cdot 7)$ & $7(2 \cdot 2)$ \\
Death before hospital admission & $3(1 \cdot 8)$ & $5(3 \cdot 4)$ & $8(2 \cdot 6)$ \\
\hline Any myocardial infarction & $125(76 \cdot 7)$ & $117(79 \cdot 1)$ & $242(77 \cdot 8)$ \\
\hline Total & $163(100)$ & $148(100)$ & $311(100)$ \\
\hline
\end{tabular}

^Includes pre-hospital deaths assumed to be due to myocardial infarction.

to have had a dissecting aneurysm of the proximal aorta affecting the left anterior descending coronary artery and causing cardiac tamponade. The true diagnosis was not recognised before death by the staff of the medical ward to which she had been admitted.

\section{Q WAVE INFARCTION}

Of patients with myocardial infarction at any of the three levels of certainty there were significantly fewer with new $Q$ wave infarcts in those given thrombolytic therapy at home rather than in hospital (table V). The reduction in $Q$ wave infarction with home thrombolysis was greater in the subset who received the home injection within two hours of the onset of symptoms compared with those who received home injection after this time $(-20 \% v-5 \%)$.

\section{STROKE DISTANCE}

Stroke distance tended to be higher in patients who were given anistreplase at home rather than in hospital, and this difference in favour of thrombolysis at home was statistically significant in those who received home injection within two hours of symptom onset (table VI).

TABLE V $-N$ umbers of patients with $Q$ wave infarction/numbers with infarction (percentages) by home injection up to two hours after onset of symptoms or later

\begin{tabular}{lccccc}
\hline $\begin{array}{l}\text { Home } \\
\text { injection }\end{array}$ & Home & Hospital & Difference & interval & p Value \\
\hline$\leqslant 2 \mathrm{~h}$ & $39 / 78(50 \cdot 0)$ & $47 / 67(70 \cdot 1)$ & $-20 \cdot 1$ & $-35 \cdot 7$ to $-4 \cdot 6$ & $0 \cdot 01$ \\
$>2 \mathrm{~h}$ & $26 / 44(59 \cdot 1)$ & $29 / 45(64 \cdot 4)$ & $-5 \cdot 4$ & $-25 \cdot 5$ to $14 \cdot 8$ & $0 \cdot 60$ \\
\hline All & $65 / 122(53 \cdot 3)$ & $76 / 112(67 \cdot 9)$ & $-14 \cdot 6$ & $-27 \cdot 0$ to $-2 \cdot 2$ & 0.02
\end{tabular}

TABLE VI-Mean stroke distance (standard deviation) expressed as percentuge of age predicted value by home injection up to two hours after onset of symptoms, or later

\begin{tabular}{|c|c|c|c|c|c|}
\hline $\begin{array}{c}\text { Home } \\
\text { injection }\end{array}$ & Home & Hospital & \% Difference & $\begin{array}{l}95 \% \text { Confidence } \\
\text { interval }\end{array}$ & $\mathrm{p}$ Value \\
\hline $\begin{array}{l}\leqslant 2 \mathrm{~h} \\
>2 \mathrm{~h}\end{array}$ & $\begin{array}{l}87 \cdot 6(20 \cdot 0)[n=100] \\
87 \cdot 2(16 \cdot 5)[n=54]\end{array}$ & $\begin{array}{l}80 \cdot 8(19 \cdot 6)[n=80] \\
89 \cdot 2(17 \cdot 7)[n=57]\end{array}$ & $\begin{array}{r}6 \cdot 8 \\
-2 \cdot 0\end{array}$ & $\begin{array}{l}1.0 \text { to } 12.7 \\
-8.4 \text { to } 4.5\end{array}$ & $\begin{array}{l}0.02 \\
0.54\end{array}$ \\
\hline All & $87 \cdot 5(18 \cdot 8)[n=154]$ & $84 \cdot 3(19 \cdot 2)[n=137]$ & $3 \cdot 2$ & $-1 \cdot 2$ to $7 \cdot 6$ & $0 \cdot 15$ \\
\hline
\end{tabular}

\section{Discussion}

In Grampian it is usual for patients or their relatives to call for a doctor rather than for an ambulance in the event of a medical emergency. General practitioners are therefore well placed to provide pre-hospital coronary care. ${ }^{1019}$ Their median response time in this study was 10 minutes.

The median delay between the onset of symptoms and the patient calling for help was $\mathbf{4 5}$ minutes, shorter than in other reported studies. ${ }^{8}{ }^{19}$ This was due to the narrow time window of four hours available for trial entry, which was chosen to ensure that patients randomised to receive thrombolytic therapy in hospital could get it within six hours of symptom onset.

Because of the high risk of ventricular fibrillation soon after myocardial infarction doctors who respond quickly will encounter cardiac arrest in about $5 \%$ of heart attack calls. ${ }^{10}$ This same rate of occurrence of cardiac arrest was found in this study, where fatal or non-fatal cardiac arrests took place before hospital admission in 15 of the 311 cases $(5 \%)$. With this frequency of cardiac arrest it behoves general practitioners answering heart attack calls to be equipped and prepared for resuscitation. ${ }^{20}$

Pre-hospital coronary care was established to provide resuscitation from out of hospital cardiac arrest. ${ }^{21}$ Very soon it became apparent that the provision of general medical care in the communityrelief of pain and anxiety with opiates, correction of autonomic disturbances and arrhythmias-was itself life saving. ${ }^{22}$ Moreover, the number of lives saved indirectly by these general measures greatly exceeds the number saved by resuscitation. ${ }^{23-25}$ The lifesaving benefit of early general medical care, the humane requirement for relief of pain before transportation, and the time saving in giving thrombolytic therapy are the main arguments against the patient calling an ambulance directly and bypassing the general practitioner.

The median time saving that resulted from general practitioners giving thrombolytic therapy, at 130 minutes, was substantial, especially in relation to the 105 minutes' median duration of symptoms when the home injection was given.

The general practitioners' median door to needle time was 43 minutes, but this included the time taken to make contact with the trial coordinator and get authorisation to proceed with thrombolytic therapy. The trial admission procedure added a few minutes' delay to the home injection (and, similarly, a few minutes' delay to the hospital injection) but under nontrial circumstances thrombolytic therapy could be given at home at an earlier stage before arrangements for hospital admission were made. In the trial the recording of an electrocardiogram before the home injection caused some delay, but only in a few practices that were closest to Aberdeen, where it was not customary to record an electrocardiogram before admission to hospital.

Even in an urban area there would be a temporal advantage in the general practitioner giving thrombolytic therapy in the home, provided that he or she is able to respond rapidly to the patient's call.

\section{CLINICAL ASSESSMENT AND BENEFITS OF EARLY THERAPY}

Clinical assessments made in patients' homes soon after the onset of symptoms were remarkably accurate. In only $1 \%$ of cases $(3 / 311)$ was the admitting hospital doctor able to make an alternative diagnosis to that of the general practitioner, and the working diagnosis of suspected myocardial infarction was proved incorrect in only $2 \%$ of cases $(7 / 311)$.

In the trial the final diagnosis was acute myocardial infarction in $78 \%(242 / 311)$ of cases; $20 \%(62 / 311)$ of patients had either ischaemic heart disease or chest pain of unknown cause. 
The time savings achieved in the trial were translated into substantial benefits for patients. Three month mortality from all causes was reduced by $49 \%$, and cardiac mortality was halved by early thrombolysis.

For the survivors of acute myocardial infarction domiciliary thrombolysis was associated with a lower incidence of full thickness $Q$ wave infarction. This results in better left ventricular function in the short term and may well lead to deferred mortality benefit, since deaths during follow up are less frequent after partial thickness than after $Q$ wave infarction. ${ }^{26}$

The most important predictor of survival after myocardial infarction is left ventricular function, which in the trial was assessed as stroke distance. Stroke distance was greater in patients treated with antistreplase at home rather than in hospital, especially where thrombolytic therapy was instituted within two hours of the onset of symptoms.

The opportunity to initiate thrombolytic therapy within two hours of symptom onset occurs very infrequently in hospital but is commonly present in the community. In the trial only two (1\%) patients received their hospital injection within two hours of the onset of symptoms, whereas $189(61 \%)$ received home injection within the same time.

\section{CONCLUSIONS}

In the Grampian region early anistreplase trial the participating general practitioners provided a high standard of pre-hospital coronary care. They responded promptly, were proficient in resuscitation, and were accurate in their clinical assessment. They relieved pain with opiates, administered other drugs as necessary, and initiated thrombolytic therapy. The time saving by domiciliary thrombolysis resulted in a halving of the three month mortality, with fewer $Q$ wave infarcts and better left ventricular function in the survivors. Benefits were most marked where thrombolytic therapy was administered within two hours of the onset of symptoms.

Members of the GREAT Group were as follows:

General practitioners-R Gatenby, $\mathrm{K}$ Lyons (Aberchirder); T Stewart, J Taylor, J Scott (Aboyne); G Payne, J Reid (Alford); D Glass (Ballater); D Carroll, A McLean, G Mennie, F Mair, D Barclay, M McCrone, K Morton (Banchory); N Kennedy, J Anderson, D Innes, D Scott, C Guthrie (Banff); H Dawson (Braemar); J Kinnon, B Murray (Crimond); K Fraser (Cuminestown); W Morrison, C Burgess, A Donaldson, M Pucci, I Simpson, D McKercher, I Mackay, R Bell (Ellon); R Bichan, G Gordon, A Hayworth, R Massie, A Wisley, V Tosh, W Steele, E Wilson, R Logan, H Nicol, I McLean (Fraserburgh); A Taylor, S Robertson, R Wallace, D Connell (Fyvie-Oldmeldrum); J Rae (Gardenstown); G Ferguson, J Sandeman (Hatton); E Cosgrove, G Shirreffs, D Easton, A Sinclair, G Carter (Huntly); M Kay, H Mackie, G Morrice (Insch); V Johnston, A Fisken, J Beattie, J Black, J MacDonald, G Gill, I Cruickshank, D Hood, S Harkness, D Smylie (Inverurie); M Morrison, J Harrington, G Herd, R Hutchison, J Thomason (Keith); D Hawson, G Young, P Green, N Mack (Kemnay); I Brooker, A Barbour (Macduff); J Miller, A Gauld, T Goodbrand, R McInnes, D Nicol (Mintlaw); A Robertson, D McLeman, S Crockett (New Deer); I Taylor (Portsoy); A Morgan, G McIntosh, A Stewart, J Herd, J Smith, A MacCuish (Stonehaven); A de Laat,
A Sneddon (Strathdon); D Crowley (Tomintoul); A Duthie, R Fraser, A Smith, R Liddell (Turriff).

Cardiologists and physicians-J Bevan, P Bewsher, P Brunt, N Benjamin, G Catto, N Edward, R Himsworth, A Jeffers, $\mathrm{K}$ Jennings, A Johnston, A Kenmure, A McLeod, A Mowat, L Murchison, D Pearson, J Petrie, D Power, J Rawles,

T Sinclair, C Smith, S Walton, J Webster, $M$ Williams.

Coordinators $-\mathrm{J}$ Light, $M$ Watt.

Technician-J McKnight.

SmithKline Beecham-M Simpson, F Cree, M Wellwood.

1 Baughman KL, Maroko PR, Vatner SF. Effects of coronary artery reperfusion on myocardial infarct size and survival in conscious dogs. Circulation 1981;63:317-23.

2 Bergmann SR, Lerch RA, Fox KAA, Ludbrook PA, Welch MJ, TerPogossian M, et al. Temporal dependence of beneficial effects of coronary thrombolysis characterised by positron tomography. Am $\mathcal{F}$ Med 1982;73:
the thromboly

3 Gruppo Italiano per lo Studio della Streptochinasi nell'Infarto Miocardico (GISSI). Effectiveness of intravenous thrombolytic treatment in acute myocardial infarction. Lancet 1986; ; 397-401.

4 Second International Study of Infarct Survival Collaborative Group. Randomised trial of intravenous streptokinase, oral aspirin, both, or neither among 17187 cases of suspected acute myocardial infarction: ISIS-2,. Lancet 1988;ii:349-60.

5 AIMS Trial Study Group. Effect of intravenous APSAC on mortality after acute myocadial infarction: preliminary report of a placebo-controlled clinical trial. Lancet 1988;i:545-9.

6 Wilcox RG, von der Lippe G, Olsson CG, Jensen G, Skene AM, Hampton JR. Trial of tissue plasminogen activator for mortality reduction in acute myocardial infarction. Anglo-Scandinavian study of early thrombolysis (ASSET). Lancet 1988;ii: $525-30$.

7 European Myocardial Infarction Project (EMIP) Sub-Committee. Potential time saving with pre-hospital intervention in acute myocardial infarction. Eur Heart f 1988;9:118-24.

8 Rowley JM, Mounser P, Harrison EA, Skene AM, Hampton JR. Management of myocardial infarction: implications for current policy derived from the Nottingham heart attack register. Br Heart $\mathcal{f}$ 1992;67:255-62.

9 Petch MC. Coronary thrombolytic treatment at home. BMf 1991;302:1287-8.

10 Pai GR, Haites NE, Rawles JM. One thousand heart attacks in Grampian: the place of cardiopulmonary resuscitation in general practice. BMF 1987;294: 352-4.

11 Rawles JM. General practitioners' management of acute myocardial infarction and cardiac arrest: relevance to thrombolytic treatment. BMF 1987;295: 639-40.

12 Cobbe SM, Redmond MJ, Watson JM, Hollingworth J, Carrington DJ. "Heartstart Scotland"-initial experience of a national scheme for out of hospital defibrillation. $B M \mathcal{Y}$ 1991;302:1517-20.

13 Metcalfe MJ, Rawles JM. Stroke distance in acute myocardial infarction: a simple measurement of left ventricular function. Lancet 1989;i:1371-3.

14 Haites NE, McLennan FM, Mowat DHR, Rawles JM. Assessment of cardiac output by the Doppler ultrasound technique alone. Br Heart f 1985;53: 123-9.

15 Shah M, Taylor RT. Low back pain associated with streptokinase. BMf 1989;301:1219.

16 Dickinson RJ, Rosser A. Low back pain associated with streptokinase. $B M \mathcal{F}$ 1989;302:111-2.

17 Porter NJ, Nikoletatos $\mathrm{K}$. Low back pain associated with streptokinase. $B M \mathcal{F}$ 1989;302:111-2.

18 Maciennan AC, Ahmad N, Lawrence JR. Activities of aminotransferases after treatment with streptokinase for acute myocardial infarction. BMJ 1989; 301:321-2.

19 Rawles JM, Haites NE. Patient and general practitioner delays in acute myocardial infarction. $B M \mathcal{F}$ 1988;296:882-4.

20 Colquhoun MC, Julian DG. Treatable arrhythmias in cardiac arrests seen outside hospital. Lancet 1992;339:1167.

21 Pantridge JF, Geddes JS. A mobile intensive care unit in the management of myocardial infarction. Lancet 1967;ii:271-3.

22 Pantridge JF. The effect of early therapy on hospital mortality from acute myocardial infarction. $Q \mathcal{F}$ Med 1970;39:621-2.

23 Crampton RS, Aldrich RF, Gascho JA, Miles JR, Stillerman R. Reduction of prehospital, ambulance and community coronary death rates by the community-wide emergency cardiac care system. Am $\mathcal{J}$ Med 1975;58: 151-65.

24 Wennerblom B, Holmberg S, Wedel $\mathrm{H}$. The effect of a mobile coronary care unit on mortality in patients with acute myocardial infarction or cardiac arrest outside hospital. Eur Heart f 1982:3.504-15.

25 Mathewson ZM, McCloskey BG, Evans AE, Russell CJ, Wilson C. Mobile coronary care and community mortality from myocardial infarction. Lancet $1985 ;$; :441-4.

26 Metcalfe MJ, Rawles JM, Shirreffs C, Jennings K. Six year follow up of a consecutive series of patients presenting to the coronary care unit with acute chest pain: prognostic importance of the electrocardiogram. Br Heart $\mathcal{F}$ 1990;63:267-72.

(Accepted 30 fuly 1992) 